УДК 343.132

DOI https://doi.org/10.32844/2618-1258.2019.3-2.35

ТАРАСЮК С.М.

\title{
СПІВВІДНОШЕННЯ КОНСТИТУЦИЙНИХ ПРАВ НА НЕВТРУЧАННЯ В ПРИВАТНЕ ЖИТТЯ ТА НЕДОТОРКАННІСТЬ ПРАВА ВЛАСНОСТІ ПРИ ПРОВЕДЕННІ СЛІДЧИХ (РОЗШУКОВИХ) ДІЙ У ЖИТЛІ ЧИ ІНШОМУ ВОЛОДІННІ ОСОБИ
}

Досліджено питання сутності конституційних прав особи на невтручання в приватне життя та недоторканність права власності, їх функціональне призначення та співвідношення, нормативну базу забезпечення даних конституційних прав. Визначено учасників кримінального провадження, які $є$ носіями прав під час проведення слідчих (розшукових) дій. Проаналізовано питання допустимості обмеження конституційних прав, яке має здійснюватися на підставі закону, визначеного процесуального порядку, а також з дотриманням загальної умови невід'ємності системи основних прав і свобод.

Виокремлено слідчі (розшукові) дії, які можуть бути проведені в житлі чи іншому володінні особи, спрямовані на обмеження конституційних прав особи на невтручання в приватне життя та недоторканність права власності. Акцентовано увагу на дотриманні балансу між завданнями охорони прав особи при проведенні слідчих (розшукових) дій у житлі чи іншому володінні особи та ефективною боротьбою зі злочинністю.

Узагальнено рішення Європейського суду з прав людини щодо дотримання конституційних прав людини в кримінальному провадженні та їх обмеження. Проаналізовано випадки довільного (без достатніх підстав) втручання органів розслідування в приватне життя підозрюваного чи інших учасників кримінального провадження. Визначено механізм забезпечення конституційного права на невтручання в приватне життя під час проведення слідчих (розшукових) дій у житлі чи іншому володінні особи. Сформульовано поняття обмеження права власності.

Наголошено на важливості підвищення ролі й значення слідчого, прокурора, слідчого судді щодо забезпечення повноцінної реалізації конституційних прав особи під час проведення в іiі житлі чи іншому володінні обшуку, огляду, слідчого експерименту та інших слідчих (розшукових) дій, а також удосконалення процесуальних гарантій.

Надано пропозиції до кримінального процесуального законодавства України щодо забезпечення конституційних прав людини під час проведення слідчих (розшукових) дій у житлі чи іншому володінні особи.

Ключові слова: кримінальне провадження, право на невтручання в приватне життя, право на недоторканність власності, слідчі (розщукові) дії в житлі чи іншому володінні особи, учасники кримінального провадження.

The question of the essence of constitutional human rights to non-intervention into private life and sanctity of the home, it's functional purpose and correlation, normative base for ensuring present constitutional rights is investigated. The participants in criminal proceeding, who are bearers of the rights during the investigation are defined.

The question of the admission of restrictioning constitutional rights, which should be accomplish on the law's basis, a specific procedure order maintaining general condition of non-negativity of the system of fundamental rights and freedom is analyzed.

Investigation actions, which could takes a place at home or other person's property and aimed to restrict the constitutional human rights to non-intervention into private life and sanctity of property rights are picked out.

(C) ТАРАСЮК С.М. - керуючий партнер АО «Тарасюк і Партнери», аспірант кафедри кримінального процесу та криміналістики (Академія адвокатури України) 
Attention is focused on maintaining the balance between protection individual rights during the search actions at home or other property, and effective prevention of crime.

Summarize the decision of European Court of Human Rights on maintaining constitutional human rights in criminal proceeding and its restriction. Cases of arbitrary without sufficient reasons intervention the legislative body into private life of a suspect or other participants of the criminal proceeding are analyzed. The mechanism of ensuring the constitutional rights to non-intervention into private life during investigation in a person's home or other property is determined. The conception of restriction the property rights is formulated.

The raise of importance and role of investigator, prosecutor, judge to ensure full realization of constitutional human right during examination, search, investigation experiment at home or other property, as well as improvement of procedural guarantees is highlighted.

Suggestions to the criminal procedural legislation of Ukraine regarding to ensure constitutional human rights during investigation at home or other property are given.

Key words: criminal proceeding, right to non-intervention into private life, right of the home sanctity, investigation actions at home or other property of a person, participants in criminal proceeding.

Вступ. У сучасному світі обов'язком будь-якої цивілізованої країни є забезпечення конституційних прав людини у кримінальному провадженні, а також недопущення безпідставного втручання державних органів у зазначені права. Особливо актуальним це питання стає під час проведення слідчих (розшукових) дій у житлі чи іншому володінні особи, оскільки їх проведення завжди обмежує конституційні права людини, у тому числі на невтручання в приватне життя та недоторканність права власності.

Водночас динаміка змін, що вносяться в кримінальне процесуальне законодавство України в частині дотримання зазначених конституційних прав, їх співвідношення під час проведення в житлі або іншому володінні особи слідчих (розшукових) дій, свідчить про необхідність подальшого дослідження цього питання. В Україні цю проблему вивчали О.В. Верхогляд-Герасименко, В.І. Галаган, М.Й. Кулик, Н.С. Моргун, О.В. Музиченко, В.В. Назаров, В.О. Серьогін, О.Ю. Татаров, В.М. Тертишник, Л.Д. Удалова, О.Г. Шило та інші. Водночас дослідження кримінального процесуального законодавства України, літературних джерел, статистичних матеріалів, судово-слідчої практики дозволяє стверджувати, що сучасний етап вирішення проблеми дотримання конституційних прав на невтручання в приватне життя та недоторканність права власності під час проведення слідчих (розшукових) дій вимагає якісно нових підходів щодо розуміння такої проблеми.

Постановка завдання. Мета статті полягає в дослідженні сутності та співвідношення конституційних прав людини на невтручання в приватне життя та недоторканність права власності під час проведення слідчих (розшукових) дій, виокремленні особливостей чинного законодавства щодо допустимості їх обмеження, виявленні в законодавстві прогалин, які потребують доктринального аналізу й нормативного врегулювання.

Результати дослідження. Кримінальний процесуальний кодекс України (далі - КПК України) чітко визначає систему слідчих (розшукових) дій, нормативну особливість їх проведення під час досудового розслідування (розділ ІІІ КПК України). Однак особливе значення мають ті слідчі (розшукові) дії, які можуть бути проведені в житлі чи іншому володінні особи, а саме: обшук (ст. ст. 234, 235 КПК), огляд (ст. 237 КПК), огляд трупа, поєднаний з оглядом житла або іншого володіння особи (ст. 238 КПК), слідчий експеримент (ст. 240 КПК), обстеження публічно недоступних місць - житла чи іншого володіння особи (ст. 267 КПК), оскільки їх проведення завжди пов'язане з обмеженням конституційних прав особи.

Одним із основних конституційних прав особи, яке обмежується під час проведення таких дій, $є$ право на приватне життя. У Конституції та КПК України визначено оптимальні межі втручання в приватне життя особи, яка вчинила кримінальне правопорушення, визначено баланс між приватними та публічними інтересами. Так, відповідно до ст. 32 Конституції України ніхто не може зазнавати втручання в особисте і сімейне життя, крім випадків, передбачених Основним Законом України. Положення ч. 2 ст. 32 Конституції України передбачають вичерпні підстави можливого правомірного втручання в особисте та сімейне життя особи, якими є згода особи на 
збирання, зберігання, використання та поширення конфіденційної інформації про неї; випадки, визначені законом в інтересах національної безпеки, економічного добробуту та прав людини.

У статті 15 КПК України зазначено, що під час кримінального провадження кожному гарантується невтручання в приватне (особисте і сімейне) життя. Ніхто не може збирати, зберігати, використовувати та поширювати інформацію про приватне життя особи без її згоди, крім випадків, передбачених кримінальним процесуальним законодавством. Інформація про приватне життя особи, отримана в порядку, передбаченому КПК України, не може бути використана інакше як для виконання завдань кримінального провадження. Кожний, кому надано доступу до інформації про приватне життя, зобов'язаний запобігати розголошенню такої інформації.

Вищезазначене свідчить, що сторона обвинувачення в кримінальному провадженні зобов'язана утримуватися від незаконного вторгнення у сферу особистих і сімейних прав та інтересів учасників кримінального провадження і всіляко оберігати їх від порушень. Сторона захисту та інші учасники кримінального провадження мають право вимагати від відповідних державних органів неухильного виконання зазначеного обов'язку. Вони наділені досить широким комплексом засобів впливу на службових осіб, які забезпечують охорону й захист особистих і сімейних прав учасників кримінального провадження або їх відновлення у разі можливого обмеження чи порушення.

В.В. Михайленко з цього приводу слушно зауважив, що під час планування, організації, реалізації слідчих (розшукових) дій та фіксації їх результатів слідчий має забезпечувати і не порушувати права і свободи підозрюваного, свідка, потерпілого та інших учасників кримінального провадження. Отримання доказів 3 порушенням прав людини позбавляє їх критерію допустимості і призводить до неможливості використання для доведення чи спростування обставин, що мають значення для кримінального провадження [1, с. 91].

Загалом науковці по-різному розуміють сутність та поняття приватного життя. Так, В. Серьогін приватне життя визначає як сферу життєдіяльності людини, що являє собою сукупність явищ, які характеризують існування і визначають розвиток людини як приватної (пересічної) особи, стосуються лише іiі, не пов'язані з виконанням нею публічних функцій і вилучені 3 поля зору громадськості [2, с. 60]. Г.І. Сисоєнко приватне життя розуміє як життєдіяльність людини в особливій сфері відносин, які не підлягають контролю з боку держави, суспільних організацій, громадян [3, с. 493].

Розмаїття визначень поняття приватного життя характеризує його як складне, індивідуальне, неповторне й багатоманітне явище, у зв'язку з чим воно $є$ досить уразливим у кримінальному провадженні. ЄСПЛ у своїх рішеннях зазначив, що концепція приватного життя має досить широкий зміст і її не можна однозначно тлумачити (рішення у справах «Пек проти Сполученого Королівства» від 28 квітня 2003 р., «Прітті проти Сполученого Королівства» від 29 липня 2002 р.). Крім того, поняття застосовується в інших сферах, що захищаються ст. 8 Конвенції і стосуються сімейного життя, житла, кореспонденції [4, с. 26; 5].

Узагальнюючи, можна дійти висновку, що приватне життя $\epsilon$ фізичною, духовною, територіальною сферою, яка контролюється самим індивідом, є вільною від зовнішнього впливу. Держава не має права втручатися в цю сферу, а, навпаки, покликана захищати їі від будь-якого незаконного втручання. Інакше кажучи, поняття «приватне життя» охоплює ту галузь життєдіяльності людини, що стосується окремої особи, тобто лише іiі, і не підлягає контролю з боку суспільства та держави, якщо вона не має протиправного характеру.

У разі вчинення особою кримінального правопорушення держава в особі владних органів має втручатися в приватну сферу особи в межах, визначених законом. У зв'язку з цим під час проведення слідчих (розшукових) дій у житлі чи іншому володінні особи можуть бути вилучені ті речі чи документи, які стосуються вчиненого кримінального правопорушення. Так, можуть бути вилучені особисті документи - листи, записні книжки, щоденники, окремі записи і аркуші з нотатками, які належать конкретній особі. Напевно, особисті документи можуть містити відомості про приватне життя людини, іiї думки, міркування, ставлення до інших людей, про певні події в її житті, розголосу яких вона не бажає з певних міркувань. Завдання слідчого в такому разі полягає у недопущенні розголосу відомостей про приватне життя, особливо коли ця інформація стосується інтимного життя особи, таємниці вчинення нотаріальних дій, лікарської, комерційної, конфіденційної, а також банківської таємниці тощо.

Однак слід звернути увагу, що інформація про вчинені особою правопорушення та інші відомості, що стосуються даного правопорушення, мають суттєве значення для вирішення питання про відповідальність і не підлягають охороні як особиста або сімейна таємниця. Водночас ні сам 
власник таємниці, ні його близькі чи родичі (ст. 63 Конституції України) не можуть примушуватися до розкриття такої інформації. Необхідні для правосуддя відомості органи розслідування повинні отримувати шляхом використання наявних у них законних процесуальних можливостей.

Крім того, необхідно розуміти причини, які змушують людину тримати в таємниці певні відомості про приватне життя. Переважно ці причини зумовлені соціально-психологічним аспектом. Так, через почуття сорому людина прагне приховати від сторонніх осіб певні події свого життя. Проте приховування певної інформації про приватне життя через моральні принципи, що існують у свідомості людей, має і прагматичний бік, оскільки розголошення такої інформації може завдати реальної шкоди людині або поставити під сумнів її репутацію.

На жаль, у слідчій практиці існує безліч випадків довільного (без достатніх підстав) втручання органів розслідування в приватне життя підозрюваного чи інших учасників кримінального провадження. Крім того, частими $є$ порушення порядку проведення слідчих (розшукових) дій у житлі чи іншому володінні таких осіб, а також норм моралі і професійної етики, задіювання протиправних й аморальних прийомів, пов'язаних з використанням даних про приватне життя, 3 метою чинення тиску на таких осіб. Це підтверджується статистичними даними, відповідно до яких за період з січня 2013 р. до березня 2019 р. за ст. 182 КК України «Порушення недоторканності приватного життя» відкрито 634 кримінальні провадження [6].

На нашу думку, з метою недопущення зазначених вище порушень механізм забезпечення конституційного права на невтручання в приватне життя під час проведення слідчих (розшукових) дій у житлі чи іншому володінні особи має передбачати таке: чіткий та жорсткий судовий контроль діяльності органів розслідування; обов'язкове дотримання таємниці приватного життя, що стала відомою під час проведення слідчої (розшукової) дії; максимальне обмеження кола учасників слідчої (розшукової) дії; урахування під час добору учасників слідчої (розшукової) дії їх особистих якостей; можливість оскарження дій і рішень, що порушують дане право; кримінальна відповідальність за порушення права на недоторканність приватного життя.

У будь-якому разі під час кримінального провадження слід завжди враховувати, що забезпечення поваги до приватного життя не має бути чимось незначним чи другорядним. Сторона обвинувачення під час проведення слідчих (розшукових) дій у житлі чи іншому володінні особи має забезпечувати належну охорону та захист приватного життя осіб, які в ньому проживають, не допускати розголошення інформації про особисте й сімейне життя підозрюваного, обвинуваченого, потерпілого, інших учасників кримінального провадження. Втручання в приватне життя має здійснюватися винятково на підставі кримінального процесуального закону і лише 3 метою виявлення з усієї сукупності відомостей, що становлять таємницю приватного життя, тих, які мають протиправний характер.

Слід звернути увагу, що в разі проведення слідчих (розшукових) дій у житлі чи іншому володінні особи одночасно обмежується як конституційне право на невтручання в приватне життя, так і право на недоторканність власності. Г.М. Мамка у своєму дослідженні зазначив, що власність $є$ природним правом людини, джерелом ії волі і рівності з іншими людьми [7, с. 45].

Відповідно до ст. 41 Конституції України ніхто не може бути протиправно позбавлений права власності, право приватної власності є непорушним. Отже, недоторканність приватної власності є станом захищеності від зазіхань, забороною вчиняти будь-які дії всупереч волі власника.

Водночас конституційне право на недоторканність власності, як і право на невтручання в приватне життя, не є абсолютним під час кримінального провадження. Воно може бути обмежене у визначених кримінальним процесуальним законом випадках.

В.I. Галаган, Н.С. Моргун, М.Й. Кулик, Ю.В. Терещенко зазначили, що важливим аспектом кримінального провадження є створення передумов для того, щоб особи, яким належить майно, мали можливість реалізовувати свої повноваження щодо належного їм майна. Водночас має виконуватись завдання кримінального провадження, чого можна досягти лише за умов обмеження чи навіть позбавлення права власності під час розслідування кримінальних правопорушень $[8$, с. 4].

У статті 16 КПК України визначено, що позбавлення або обмеження права власності під час кримінального провадження здійснюється на підставі вмотивованого судового рішення, ухваленого в порядку, передбаченому КПК, а також на підставах та в порядку, передбачених КПК. При цьому допускається тимчасове вилучення майна без судового рішення.

Чинне кримінальне процесуальне законодавство України під час досудового розслідування допускає обмеження права на недоторканність власності під час проведення слідчих (розшу- 
кових) дій, негласних слідчих (розшукових) дій, а також під час застосування заходів забезпечення кримінального провадження.

На думку Г.М. Куцкір, обмеженням права власності в кримінальному провадженні є зовнішня дія на суб' єктивне право власності конкретної особи, яка втілюється у відповідних кримінально-процесуальних правовідносинах з ії участю, тягне за собою виникнення певних правових труднощів, звуження, зменшення можливостей здійснення власником своїх повноважень і полягає в конкретних приписах власнику вчинити певні дії або утриматися від їх учинення [9, с. 95]. O.B. Музиченко обмеження права власності визначає як передбачене законом тимчасове звуження можливостей здійснення конкретних суб'єктивних прав окремими учасниками кримінального провадження або іншими особами з боку суб'єктів, які проводять досудове розслідування та судовий розгляд [10, с. 147].

3 огляду на зазначене спробуємо сформулювати своє розуміння обмеження права власності. Ми вважаємо обмеженням права власності під час досудового розслідування є передбачене кримінальним процесуальним законодавством України тимчасове звуження обсягу та можливостей здійснення правомочностей власника, які полягають в обов'язку утримуватися від будь-яких дій або зазнавати правообмежувальних дій з боку суб'єктів, наділених владними повноваженнями.

Окремо зазначимо, що обмеження права власності під час досудового розслідування має засновуватися на законі, мати легітимну мету, бути необхідним для суспільства, держави чи сприяти охороні або захисту прав інших осіб, а також має бути тимчасовим, тобто за умови зникнення підстав, які спричинили застосування обмежень, право власності має бути автоматично відновлене.

3 урахуванням предмета нашого дослідження зазначимо, що право на недоторканність власності найбільш суттєво обмежується в разі проведення обшуку, огляду житла чи іншого володіння особи, а також проведення такої негласної слідчої (розшукової) дії, як обстеження публічно недоступних місць. Практика ЄСПЛ свідчить, що власність може бути обмежена під час проведення відповідних дій, але у співмірних межах. Так, ЄСПЛ у прийнятому у справі «Спорронг і Лоннрот проти Швеції» рішенні зазначив, що обмеження у використанні приватної власності мають залишити власнику певний ступінь свободи, інакше такі обмеження рівнозначні позбавленню власності [11].

Найсуттєвіші обмеження права власності під час проведення слідчих (розшукових) дій у житлі чи іншому володінні особи виникають в разі проведення обшуку. Зокрема, відповідно до ч. 1 ст. 234 КПК України обшук проводиться з метою виявлення та фіксації відомостей про обставини вчинення кримінального правопорушення, пошуку знаряддя кримінального правопорушення або майна, здобутого в результаті його вчинення, а також установлення місцезнаходження розшукуваних осіб. Вітчизняні науковці Н.О. Марчук, В.В. Касько, Р.О. Куйбіда, М.І. Хавронюк розрізняють ще й таку мету обшуку, як відшукання та вилучення речей і документів, зазначених в ухвалі про тимчасовий доступ до речей і документів, яку не було виконано [12, с. 119].

Зарубіжний досвід також засвідчує, що обшук може бути проведений з іншою метою. Так, відповідно до кримінального процесуального законодавства Грузії обшук може проводитися, зокрема, з метою виконання ухвали про накладення арешту на майно (ч. 1 ст. 157 КПК Грузії) [13]. Згідно з ч. 1 ст. 207 КПК Молдови в разі наявності підстав вважати, що власник або володілець приховує майно, на яке необхідно накласти арешт, орган кримінального переслідування має право проводити обшук відповідно до своїх законних повноважень [14].

3 огляду на зазначене вважаємо за доцільне ч. 1 ст. 234 КПК України викласти у такій редакції: «Обшук проводиться з метою: 1) виявлення та фіксації відомостей про обставини вчинення кримінального правопорушення; 2) відшукання знаряддя кримінального правопорушення або майна, яке було здобуте у результаті його вчинення; 3) установлення місцезнаходження розшукуваних осіб; 4) відшукання та вилучення речей і документів у разі невиконання ухвали про тимчасовий доступ до речей і документів; 5) виконання ухвали про накладення арешту на майно, якщо власник або володілець приховує майно, на яке необхідно накласти арешт».

Пропонуємо також ч. 1 ст. 164 КПК України доповнити п. 9, який викласти в такій редакції: «Розпорядження про проведення обшуку в разі відмови володільця або власника видати речі й документи, які зазначені в ухвалі про тимчасовий доступ до речей і документів». У такому разі має бути виключена з норм КПК України ст. 166 «Наслідки невиконання ухвали слідчого судді, суду про тимчасовий доступ до речей і документів».

Крім того, пропонуємо ч. 5 ст. 173 КПК України доповнити п. 6 такого змісту: «Розпорядження про проведення обшуку, якщо є підстави вважати, що власник або володілець приховує майно, на яке необхідно накласти арешт». 
Украй актуальним питанням також є недопущення безпідставного пошкодження майна під час обшуку. Відповідно до ч. 6 ст. 236 КПК України слідчий, прокурор під час проведення обшуку мають право відкривати закриті приміщення, сховища, речі, якщо особа, присутня при обшуку, відмовляється їх відкрити (обшук здійснюється за відсутності осіб, зазначених у частині третій цієї статті). Проте у КПК України не зазначено, що слідчий, прокурор мають уникати не зумовлених необхідністю пошкоджень дверей, замків й інших предметів. Ми погоджуємося з думкою О.В. Верхогляд-Герасименко, що слідчий повинен обрати такий спосіб відкриття замкнених приміщень і сховищ, за якого відкриття можливе 3 найменшим пошкодженням майна $[15$, c. 138$]$.

Проблемним питанням також вважається ведення чіткого обліку і фіксації в протоколі обшуку вилученого. Негативним прикладом цього стало проведення у 2014 році працівниками прокуратури м. Києва і міліції обшуку в магазині “Graff” у центрі Києва, в результаті якого було незаконно привласнено відповідними посадовими особами ювелірні вироби і годинники. За цим інцидентом було відкрито три кримінальні справи за крадіжку, привласнення майна, перевищення повноважень і підробку. Згідно з рішенням суду від 18.12 .2018 р. власники ювелірного магазину “Graff”, який фактично був пограбований правоохоронцями під час обшуку, відсудили в держави 25,4 млн гривень [16].

Висновки. Конституційні права на невтручання в приватне життя та недоторканність права власності під час проведення слідчих (розшукових) дій у житлі чи іншому володінні особи необхідно розглядати як домінанти прав людини. Що надійнішою буде їх охорона та захист, то вищим стане рівень законності під час кримінального провадження. Від рівня їх забезпеченості значною мірою залежать ступінь досконалості самої особистості, її недоторканність і безпека. Крім того, слідчий, прокурор, проводячи слідчі (розшукові) дії у житлі чи іншому володінні особи, мають усвідомлювати, що відповідні конституційні права людини є найвищою цінністю, їх обмеження допускається в мінімальних межах, визначених винятково необхідністю забезпечити права і свободи інших людей та інтереси суспільства, а можливості обмеження прав особистості регламентовані і перебувають на судовому контролі.

\section{Список використаних джерел:}

1. Михайленко В.В. Реалізація верховенства права при провадженні слідчих (розшукових) дій. Вчені записки Таврійського начіонального університету імені В.І. Вернадського. Серія «Юридичні науки». Том 29 (68). Київ, 2018. № 1. С. 89-97.

2. Серьогін В. Зміст і обсяг права на недоторканність приватного життя (прайвесі). Вісник Академії правових наук. 2010. № 4. С. 88-97.

3. Сисоєнко Г.І. Інформаційні права особи. Захист прав, свобод і законних інтересів громадян у процесі правоохоронної діяльності : матеріали міжвузівської наук.-практ. конф., м. Донецьк, 27 квіт. 2001 року. Донецьк : ДІВС, 2001. С. 491-494.

4. Ахтирська Н., Філатов В., Фулей Т. Стаття 8 Конвенції про захист прав людини і основоположних свобод: стандарти застосування при здійсненні правосуддя. Київ : Істина, 2011. 200 с.

5. Право на повагу до приватного життя відповідно до статті 8 Європейської Конвенції захисту прав людини та основних свобод. URL: http://khpg.org/index.php?id=1094815937.

6. Єдиний звіт про кримінальні правопорушення. URL: http://www.gp.gov.ua/ua/stst2011. html?dir_id $=110381 \&$ libid $=100820 \& \mathrm{c}=$ edit\&_c $=$ fo\#.

7. Мамка Г.М. Засади кримінального провадження: наукові та правові основи : дис. ... докт. юрид. наук : 12.00.09. Київ, 2019. 478 с.

8. Галаган В.І., Моргун Н.С., Кулик М.Й., Терещенко Ю.В. Реалізація недоторканності права власності під час досудового розслідування : навч. посіб. Київ : НАВС, 2016. 141 с.

9. Куцкир Г. Начало неприкосновенности права собственности в уголовном процессе Украины: сущность и нормативное содержание. Закон и Жизнь (Legea si Viata). 2014. С. 93-97.

10. Музиченко О.В. Поняття, зміст та стандарти обмеження принципу недоторканності права власності в кримінальному процесі України. Науковий вісник Міжнародного гуманітарного університету . 2015. № 15. Том 2. С. 146-148.

11. Спорронг (Sporrong) и Лоннрот (Lonnroth) против Швеции : судебное решение Европейского суда по правам человека от 23 сент. 1982 г. URL: http://europeancourt.ru/uploads/ECHR Sporrong_and_Lonnroth_v_Sweden_23_09_1982.pdf.

12. Марчук Н.О., Касько В.В.В., Куйбіда Р.О., Хавронюк М.І. Настільна книга професійного судді (кримінальне провадження). Київ : Арт-Дизайн, 2015. 258 с. 
13. Уголовно-процессуальный кодекс Республики Грузия : Закон Республики Грузия от 09.10.2009 г. URL: http://pravo.org.ua/files/Criminal\%20justice/_-09_10_2009.pdf.

14. Уголовно-процессуальный кодекс Республики Молдова : Закон Республики Молдова от 14.03.2003 г. URL: http://pravo.org.iia/files/Criminal\%20justice/_-09_10_2009.pdf.

15. Верхогляд-Герасименко О.В. Забезпечення майнових прав особи при застосуванні заходів кримінально-процесуального примусу : монографія. Харків : Юрайт, 2012. 216 с.

16. Відеозапис із камери магазину, яка працювала в момент обшуку, суд не прийняв як доказ. URL: https://ua.korrespondent.net/city/kiev/4051102-yuvelirnyi-mahazyn-vidsudyv-25-mlnhryven-za-pohrabuvannia-pid-chas-obshuku.

УДК 343.85:343.347

DOI https://doi.org/10.32844/2618-1258.2019.3-2.36

ТОММА Р.П., ШЕВЧУК О.О.

\section{ОРГАНІЗАЦЙНІ ОСНОВИ ПРОТИДІЇ ЗЛОЧИНАМ У СФЕРІ ОБІГУ ФАЛЬСИФІКОВАНИХ ЛІКАРСЬКИХ ЗАСОБІВ}

Стаття присвячена вивченню шляхів удосконалення організаційних основ протидії злочинам у сфері обігу фальсифікованих лікарських засобів, суспільної небезпеки цих злочинів та розробці заходів щодо їх усунення. Також у статті на основі практичних та наукових напрацювань визначено типові способи вчинення злочинів у сфері обігу фальсифікованих лікарських засобів. Визначено такі типові способи вчинення правопорушень у процесі організації та проведення процедур державної закупівлі лікарських засобів та виробів медичного призначення: закупівля лікарських засобів, виробів медичного призначення фармацевтичних послуг повністю або частково за рахунок державних коштів без проведення процедури конкурсних торгів на суму, що дорівнює або перевищує 100 тис. грн; закупівля робіт повністю або часткоаво за рахунок державних коштів без проведення процедури конкурсних торгів на суму, що дорівнює або перевищує 300 тис. грн; незаконний поділ замовником лікарських засобів та медичного обладнання на частини 3 метою уникнення проведення процедури відкритих торгів, що призводить до перевитрат державних коштів; встановлення замовником торгів дискримінаційних умов до деяких учасників процедури закупівлі. 3'ясовано, що правовий важіль впливу - це основний координаційний інструмент регулювання з метою зменшення злочинних проявів у сфері державних закупівель. 1 червня 2010 р. прийнято Закон України «Про здійснення державних закупівель», що встановлює правові та економічні засади здійснення закупівель товарів, робіт і послуг за державні кошти. Зроблено висновок, що сфера обігу лікарських засобів та медичного обладнання $\epsilon$ функціонально орієнтованим елементом національної безпеки, вбудованим в механізм бюджетного сектора економіки, ресурсно-економічного та фінансового забезпечення галузей державного управління. Протидія злочинам у сфері обігу фальсифікованих лікарських засобів полягає у виявленні причин та умов їх вчинення та розробці заходів щодо їх усунення, забезпеченні протидії кримінально-корупційним проявам витрачання бюджетних коштів під час закупівлі лікарських засобів, дотриманні необхідної їх якості та максимально повного використання принципу прозорості учасниками ринку лікарської продукції.

Ключові слова: фальсифіковані лікарські засоби, держсавні закупівлі, протидія злочинам, лікарські засоби, вироби медичного призначення, розпорядники державних коштів.

(C) ТОММА Р.П. - кандидат юридичних наук, доцент, доцент кафедри оперативно-розшукової діяльності (Національна академія внутрішніх справ)

(C) ШЕВЧУК О.О. - кандидат юридичних наук, доцент, доцент кафедри забезпечення фінансової безпеки та фінансового розслідування (Навчально-науковий інститут № 1 Національної академії внутрішніх справ) 